\title{
Regulatory $T$ cell subsets in filarial infection and their function
}

\section{Simon Metenou and Thomas B. Nutman*}

Helminth Immunology Section, Laboratory of Parasitic Diseases, National Institutes of Health, Bethesda, MD, USA

\section{Edited by:}

Eyad Elkord, United Arab Emirates University, UAE; University of Salford and University of Manchester, UK

Reviewed by:

Rick M. Maizels, The University of Edinburgh, UK

Matthew Taylor, The University of Edinburgh, UK

\section{*Correspondence}

Thomas B. Nutman, Helminth Immunology Section, Laboratory of Parasitic Diseases, National Institutes of Health, 4 Center Dr. Building 4 Room B1-03, Bethesda, MD 20892. USA

e-mail: tnutman@naiaid.nih.gov
Filarial infections in humans are chronic infections that cause significant morbidity. The chronic nature of these infections with continuous antigen release is associated with a parasite-specific $T$ cell hypo-responsiveness that may over time also affect the immune responses to bystander antigens. Previous studies have shown the filarial parasite antigenspecific T cells hypo-responsiveness is mediated by regulatory cytokines - IL-10 and TGF- $\beta$ in particular. Recent studies have suggested that the modulated/regulated T cell responses associated with patent filarial infection may reflect an expansion of regulatory $T$ cells (Tregs) that include both Tregs induced in peripheral circulation or pTregs and the thymus-derived Tregs or tTregs. Although much is known about the phenotype of these regulatory populations, the mechanisms underlying their expansion and their mode of action in filarial and other infections remain unclear. Nevertheless there are data to suggest that while many of these regulatory cells are activated in an antigen-specific manner the ensuing effectors of this activation are relatively non-specific and may affect a broad range of immune cells. This review will focus on the subsets and function of regulatory $T$ cells in filarial infection.

\section{INTRODUCTION}

\section{BACKGROUND}

Among the eight filarial humans, four - Wuchereria bancrofti, Brugia malayi, Onchocerca volvulus, and Loa loa - are considered to be the most pathogenic. These vector-borne parasites cause chronic helminth infections that have infected approximately 200 million people in the tropical and subtropical regions of the world (1-5). In endemic areas, epidemiological studies have grouped people into three major categories based on the presence of parasites and/or the presentation of clinical symptoms. These include: (1) endemic normal (or putatively immune) individuals who, despite chronic exposure to the infectious agents, appear to have no signs of infection and/or pathology; (2) those with pathology or obvious clinical symptoms (e.g., lymphedema in lymphatic filariasis (LF), ocular, or skin disease in onchocercosis, Calabar swelling in loiasis); and (3) those with subclinical infection who often have circulating microfilariae or parasite antigen. It is thought that each of these varying clinical outcomes reflects to some extent the nature of the immune (regulatory or inflammatory) response (6-12). Moreover, these asymptomatic individuals are known to have a diminished parasite-specific $\mathrm{CD} 4+$ proliferative and cytokine (particularly IL-2, IFN- $\gamma$ ) responses; with longstanding infection, this modulated parasite-specific response appears to extend to non-filarial (bystander) antigens including orally- and parenterally delivered vaccines (13-26). Although there have been a significant number of studies examining the immunological aspects of $L$. loa, $O$. volvulus, $W$. bancrofti, and B. malayi infections in humans, very few have investigated the subsets and the function of regulatory $\mathrm{T}$ cells in these infections. Though initial epidemiological and immune response studies were done in human populations, the majority of studies investigating the mechanisms underlying the regulation of these immune responses have been performed in animal studies. For instance, although antigen-specific $\mathrm{T}$ cell hypo-responsiveness in filarial infection was first described in human in in vitro systems, studies investigating role played by regulatory $\mathrm{T}$ cells have been carried out in murine models of filarial infection. Moreover, with accumulating evidence that multiple subsets of regulatory $\mathrm{T}$ cells exist, based on the expression of particular transcription factors, their origin and/or the regulatory cytokines they produce (27-31), animal models have been critical in understanding the function of a given subset in the context of filarial infection. Thus, the present review will focus on the different subsets of regulatory $\mathrm{T}$ cells in the context of chronic filarial infection (mostly $W$. bancrofti and O. volvulus) of humans as well as in studies using relevant animal models.

\section{IMMUNE REGULATION IN FILARIAL INFECTIONS}

Early studies of immune responses in LF showed that while individuals with circulating microfilariae showed impaired filarialspecific lymphoproliferative responses and cytokine (IL-2 and IFN- $\gamma$ ) production, cells from individuals free of parasites and free of clinical symptoms (so-called endemic normals) and from those with lymphedema (but no circulating filarial antigenemia) proliferated vigorously and produced measurable levels of cytokines to filarial parasite antigen $(6,32-37)$. Because all of these earlier studies were cross-sectional and in human populations, it remained unclear how the down-regulated antigen-specific $\mathrm{T}$ cell response in those with patent infection got established. However, based on animal models of filarial infection (e.g., Litomosoides or Brugia) and some limited studies in vitro using human cells exposed to 
infectious stage larvae (38-42), in our opinion the majority of data point to time-dependent early response to filarial parasites in which the mammalian-adapted infective larvae (L3) induce a local inflammatory response that is followed by a mixed type 1 (Th1) and type 2 (Th2) T cell response with higher levels of IL-4 and IL-5 cytokines (43-46). At the time of patency (that is when microfilariae appear in the blood or skin) there is (again based on varying animal models with different times to patency $(45,47)-\mathrm{a}$ change in the parasite-specific immune response in which a Th2expanded immune response occurs (with a concurrent contraction of the Th1 response) that is followed by a modulated (regulated) response that is mediated by IL-10 and TGF- $\beta$ (among others) (48-52).

That soluble factors and suppressive cells might mediate the immune hypo-responsiveness associated with chronic filarial infection was first suggested by work in a B. malayi-endemic region of Indonesia (19). Furthermore using animal models, it has been shown that the suppression of filarial-specific immune response during chronic filarial infection was mediated by nonspecific suppressor cells (33). In fact, it was known since the early 1970s that T cells mediated some of the suppression of immune responses engendered in mice; by the mid 1990s regulatory T cells were identified in mice followed subsequently by their having been found in humans (53-59).

Though regulatory $\mathrm{T}$ cells were discovered about two decades ago, questions remain about their basic biology, their mode of action, and their therapeutic potentials. Moreover, a number of regulatory $\mathrm{T}$ lymphocytes (Tregs) have been described. Based on the expression of the canonical transcription factor Foxp3, two Foxp3+ subsets have been identified: the regulatory T cells (Tregs) that are thymus-derived (tTregs) and those that are induced in the periphery from naïve Foxp3-T cells or pTregs (60). In addition to the Foxp3-expressing Tregs, two other subsets that do not express Foxp3 have been described based on the regulatory cytokines expressed by those cells. These include the type 1 regulatory $\mathrm{T}$ cells ( $\operatorname{Tr} 1)$ that express mainly IL-10 and the TGF- $\beta$ expressing Th3 regulatory T cells $(27,28,61-65)$. Each of the Treg subsets has been identified in the peripheral blood of filarial-infected patients.

Following the discovery of the transcription factor forkhead box P3 (Foxp3) being a canonical marker of regulatory T cells (66, 67), work investigating the role of these $\mathrm{T}$ cells in the context of chronic filarial infection was undertaken. Indeed, by the use of multiparameter flow cytometry and qPCR, several studies showed that chronic filarial infection was associated with increased expression of Foxp3-expressing CD4+ cells as well as Foxp3 negative CD4+ cells that expressed IL-10 (68-70). These studies revealed that in patent filarial infection the immune environment is dominated by increased frequencies of regulatory $\mathrm{T}$ cells some of which being Foxp3-expressing T cells.

\section{ROLE OF THE CYTOKINES IL-10 AND TGF- $\beta$}

Although IL-10 and TGF- $\beta$ were originally thought to be produced by Th2 cells and can be produced by various cell types including regulatory $\mathrm{T}$ cells, it has been shown that the major sources of IL-10 and TGF- $\beta$ are $\operatorname{Tr} 1$ and Th3 respectively (7178). Immune responses to filarial infection have been shown to be stage-specific with cytokines such as IL-4, IL-2, IFN- $\gamma$, IL-5, and IL-13 in association with IgE dominating the acute phase of the infection while levels of regulatory cytokines such as IL10 and TGF- $\beta$ and the antibody isotype IgG4 being elevated during the chronic phase of the infection (79-83). The role of the cytokines IL-10 and TGF- $\beta$ in the modulation of immune responses during patent filarial infection was largely inferred from studies demonstrating that neutralizing antibodies to IL-10 (and to a lesser extent TGF- $\beta$ ) significantly increased the down-regulated antigen-specific proliferative responses in patients with subclinical microfilaremic $W$. bancrofti infection (1). In similar studies in Haiti ( $W$. bancrofti-endemic) data emerged to show that cells from microfilaremic subjects also showed an inverse relationship between proliferative response to filarial antigens and IL-10 production in filarial-infected individuals (84). Since these initial studies, others have extended these by demonstrating that high levels of IL-10 were produced spontaneously (exvivo) and in response to parasite antigen stimulation in filarial-infected individuals (85, 86). Additional studies using neutralizing antibodies to IL-10 (as well as TGF- $\beta$ ) reversed both the T cell hypo-responsiveness and cytokine production to filarial antigen observed in filarial-infected patients $(1,69,87,88)$ and also reversed some of the modulation seen to the response to bystander antigens (24). The critical role of IL-10 in modulating immune responses during chronic filarial infection has been shown most notably in animal models of infection. In fact, it has been shown that mice treated with anti-IL-10 neutralizing antibody or in IL-10 deficient mice had lower microfilaremia (with B. malayi) compared with isotype treated or wild type mice (89).

In addition to directly suppressing immune responses IL-10 and TGF- $\beta$ may indirectly regulate not only the antibody response to filarial antigens but also the function of antigen presenting cells (APCs) $(1,49,52,90)$. In fact, it has been shown that IgG4 is associated with patent filarial infection while IgE was associated with the acute phase of the infection (79, 82, 83, 91-94). Furthermore, IgE and IgG4 seem to be strongly induced in filarial infection; while IgE appears very early in the infection, IgG4 levels rises exponentially following the production of microfilaremia.

The mixed IgE/IgG4 seen in chronic filarial infection may reflect the cytokine environment that dominates the immune environment during chronic infection. In fact, it has been shown that patent filarial infection is characterized by a modified Th2 response that is associated with increased frequencies of IL-4and IL-10-producing CD4 T cells $(70,95)$. Moreover, IgG4 has been used as a marker of filarial infection diagnosis but also as a marker of immunoregulation $(96,97)$. Although direct evidence for filarial-induced IL-10 to be involved in the induction of IgG4 class switching has not been established, it has been shown that IL-10 can act on human B cells and induce the production of IgG4 $(98,99)$. Furthermore, Satoguina and collaborators showed tetanus-specific regulatory $\mathrm{T}$ cells clone producing high levels of IL-10 and TGF- $\beta$ induced the production of IgG4 by naive and memory B cells in a GITR/GITRL-, TGF- $\beta$-, and IL-10-dependent manners (100). In addition to modulating antibody responses, it has been shown that chronic filarial infection modulates the function of APCs. In fact, APCs from filariainfected animals appear to promote $\mathrm{T}$ cell unresponsiveness (49, 90, 101-104). 


\section{REGULATORY T CELLS IN FILARIAL INFECTION}

With the identification of CD25+CD4+ T cells as a subpopulation responsible for controlling autoimmunity and for downregulating immune responses in mice $(54-56,105)$, these regulatory $\mathrm{T}$ cells (Tregs) were demonstrated in humans at relatively consistent levels in human peripheral blood $(57,58,106)$. In patients with LF, it was first demonstrated that Foxp3, CTLA-4, TGF- $\beta$, and PD1 expression in bulk PBMCs were significantly increased in filaria-infected individuals (69). Concurrently, several studies in mouse models of filarial infection and in human populations showed that filarial infection was associated with increased frequencies of these Tregs (70, 107-111). Using a non-permissive mouse model of infection with $B$. malayi, it was then shown that mice infected with either infective stage larvae or implanted with adult parasites expanded a population of CD4+Foxp3+ T cells that also expressed CD25, CD103, and CTLA-4 (107). Using multicolor flow cytometry in a filarial-infected group of patients in Mali, it was further shown that human filarial infection was also associated with an increased frequency not only of Tregs that were CD4+CD25+Foxp3+CD127-, but also of CD4+CD25-Foxp3 - cells producing only IL-10 [characteristic of type 1 regulatory $(\operatorname{Tr} 1)$ cells] (70).

Several studies have reported an increased frequency of Foxp3expressing Tregs in filarial infection in humans and in animal models $(69,70,107,110,112)$ though the differentiation between tTregs and pTregs in peripheral blood circulation has not been addressed clearly to date $(29,31,113,114)$. Recently, using a mouse model of the intestinal helminth parasite Heligmosomoides polygyrus, it has been demonstrated that E/S products of this parasite contained a TGF- $\beta$-like molecule that was sufficient to induce in vitro the differentiation of Foxp3-expressing Tregs or iTregs (115). Although this induction of iTregs by filarial parasites has not been assessed in humans, it has been shown that infection of mice with human filarial parasite B. malayi or the murine filarial parasite L. sigmodontis induce early expression of Foxp3 and recruitment of Foxp3-expressing regulatory T cells $(107,109,110)$. Furthermore, it has been shown that all filarial parasites examined to date do express a homolog of human TGF- $\beta$ (116-119). Furthermore, using onchocercomas collected from patients in West Africa, immunohistochemical staining showed that dead (but not live) Onchocerca adult worms in these onchocercomas were surrounded by Foxp3-expressing T cells. Whether this increased frequency of Foxp3-expressing $\mathrm{T}$ cells was the result of increased accumulation of tTregs or a local induction of pTregs within the tissue remains to be determined (120).

Although the difference between tTregs and pTregs has not been clearly established in filarial infection, several studies using human $\mathrm{T}$ cell cloning and others in mouse animal models of filarial infection have investigated $\operatorname{Tr} 1$ and $\mathrm{Th} 3$ regulatory $\mathrm{T}$ cells in filarial infection. $\mathrm{T}$ cell clones from patients with onchocerciasis were shown to produce high levels of IL-10 and TGF- $\beta$ in response to parasite antigen; these cells were shown to be either $\operatorname{Tr} 1$ (IL10 -producing) or Th3 (TGF- $\beta$ producing) cells (50). Likewise cloned $\mathrm{T}$ cells that produced neither IL- 2 nor IL- 4 but substantial amounts of IL-10 (characteristics of $\operatorname{Tr} 1$ ) that inhibited the function of other $\mathrm{T}$ cells in vitro was demonstrated from patients in Ghana (121). When looked at systematically, studies in filarial-infected patients from West Africa (but evaluated in North America) demonstrated that the major $\mathrm{T}$ cell source of IL-10 comes from CD4+CD25- cells (that are likely $\operatorname{Tr} 1$ cells) (122). These data have been supported by multiparameter flow cytomtetry based frequency analysis as well (70).

\section{FUNCTION OF REGULATORY T CELL SUBSETS IN FILARIAL INFECTION}

Several mechanisms by which Tregs (tTregs/pTregs, Tr1, and Th3) mediate their suppressive functions have been investigated in the settings of chronic filarial infection (Figure 1). Though their mode of action is not very clear, it is thought that tTregs and pTregs (at least) mediate their suppressive function through cell to cell interaction through surface molecules such as CTLA-4, GITR, LAG-3, and membrane-bound TGF- $\beta$ (123-127). In chronic filarial infection settings studies investigating the mechanisms underlying the immune hypo-responsiveness showed that CD4+ cells from filaria-infected individuals not only expressed high levels of CTLA-4 but that antibody blockade of CTLA-4 in in vitro cultures increased filarial antigen-specific proliferative response and cytokine production (87). Likewise, it has been shown that antibody blockade of CTLA- 4 and TGF- $\beta$ in vitro, increased the expression of IFN- $\gamma$, TNF- $\alpha$, IL-4, IL-5, GATA-3, and Tbet messenger RNA by cells from filaria-infected subjects in response to parasite antigen stimulation (69).

In vivo depletion of regulatory $\mathrm{T}$ cells using anti-CD25 and antibody in combination with anti-GITR antibody in a mouse model of filarial infection demonstrated enhanced production of IL-4, IL-5, and IL-10 in response to parasite antigen stimulation in vitro (109). In addition these authors showed that neutralization of CTLA- 4 and depletion of CD4+CD25 regulatory T cells in combination increased parasite-specific antibody production and enhanced worm killing (108).

Though the direct effect of filaria-induced Tregs on APC has not been evaluated formally, several studies have shown that APCs from those with patent filarial infection have altered phenotypes and diminished function (49, 90, 101, 103, 104, 128-133). Although the mechanisms underlying the modulation of APC function in patent filarial remain obscure, several studies suggested that the regulatory cytokines TGF- $\beta$ and IL-10 might involved. Furthermore it has been shown that tTregs and/or pTregs modulate APC function through molecules such as CTLA-4, GITR, LAG-3, and membrane-bound TGF- $\beta$ (123-127).

Though the role of tTregs and pTregs in the context of human filarial infection remains elusive, the other regulatory $\mathrm{T}$ cells subsets act thought the production and secretion of IL-10 and TGF- $\beta(1,69,87,88)$. Although these regulatory cytokines can be produced by different types of CD4 T cells including tTregs and pTregs, in the setting of filarial infection, it has been showed that the principal sources of IL-10 and TGF- $\beta$ are $\operatorname{Tr} 1$ and Th3 cells respectively $(50,70,121,122)$. Using animal models of filarial infection it has been shown that these regulatory cytokines particularly IL-10 directly regulate immune response to filarial parasites $(89,134)$. These regulatory cytokines elevated in the serum of chronically infected individuals and together with Foxp3-expressing surface markers have been shown to also modulate in these individuals immune responses to 


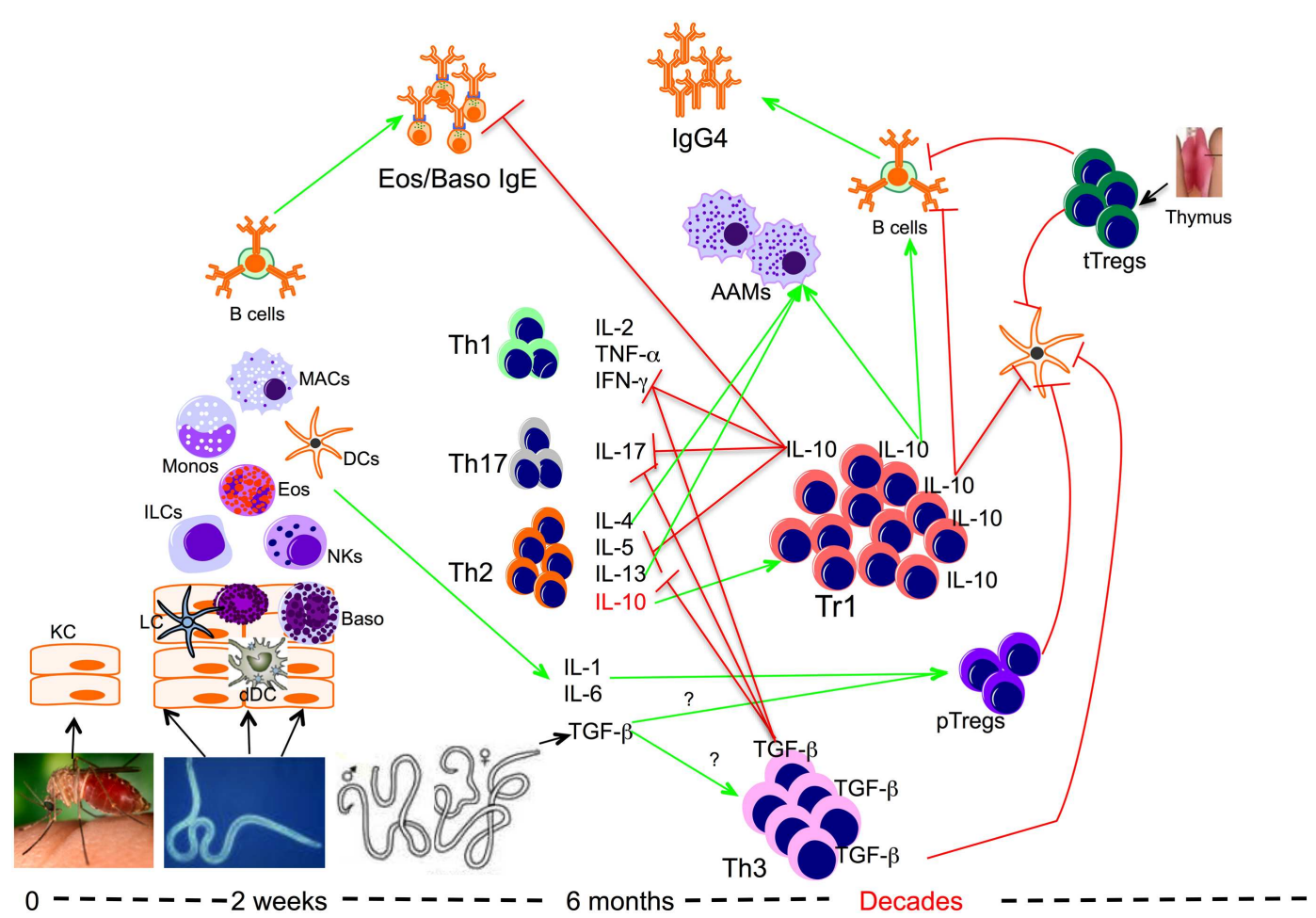

FIGURE 1 | Role of regulatory T cells in the context of filarial infection Filarial parasite infective larvae (L3) deposited on the skin during the bite of an infective mosquito actively penetrate the skin following which they migrate to a draining lymph node. During their migration, L3 contacts and activates different cells such as keratinocytes $(\mathrm{KC})$, dermal dendritic cells (dDC), innate lymphoid cells (ILCs), macrophages (MAC), dendritic cells (DCs), and basophils (Baso). At this relatively early phase of infection the parasite induces the differentiation of effector Th1, Th17, and Th2 cells, which together with IgE antibody may lead to attrition of some of the parasites. However if there is failure to clear the parasites, the infection evolves into a chronic longstanding infection associated with IL-10-producing type 1 (Tr1), TGF- $\beta$-producing Th3, and Foxp3-expressing Tregs or peripheral Tregs (pTregs), which together with the thymus-derived Tregs (tTregs) can be found with increasing frequencies in filarial infections. The high levels of IL-10 produced induce the production of $\operatorname{lgG} 4$ and together with IL-4, IL-13, and/or TGF- $\beta$ induce the differentiation of alternatively activated macrophages (AAM) and inhibit the function of a variety of other cells. non-filarial antigens including malarial antigens (24, 25, 135-138), mycobacterial antigens (139), and antigens associated with type 1 diabetes $(140,141)$.

\section{CONCLUSION}

Despite the rapidly accumulating evidence acknowledging the existence of multiple subsets of Tregs and their general modulation of immune responses, the understanding of the molecular mechanisms of their mode of action is still limited. What is clear in chronic filarial infection is an association of infection with increases of most of the Tregs subsets; however it is the dominance of IL-10-mediated regulation that seems to be the most consistent finding suggesting that the $\operatorname{Tr} 1$ cells (along with conventional IL-10-producing Th2 cells) play the major role.

\section{REFERENCES}

1. King CL, Mahanty S, Kumaraswami V, Abrams JS, Regunathan J, Jayaraman $\mathrm{K}$, et al. Cytokine control of parasite-specific anergy in human lymphatic filariasis. Preferential induction of a regulatory $\mathrm{T}$ helper type 2 lymphocyte subset. $J$
Clin Invest (1993) 92(4):1667-73. doi:10.1172/JCI116752

2. Hoerauf A, Pfarr K, Mand S, Debrah AY, Specht S. Filariasis in Africa - treatment challenges and prospects. Clin Microbiol Infect (2011) 17(7):977-85. doi:10.1111/j. 1469-0691.2011.03586.x

Delineating the subsets and function of Tregs is of capital importance as this would provide insight into their model of action and enhance their use as potential therapeutic targets. Despite recent advances in the understanding of Treg functions the lack of simple surface expressed markers for each subset has hindered some of the fundamental research on their mechanisms of action. Despite this lack of mechanistic insight, these regulatory $\mathrm{T}$ cells are clearly responsible for the modulation of parasite antigen-specific responses so characteristic of patent filarial infections.

\section{ACKNOWLEDGMENTS}

This work was supported by the Intramural Research Program of the Division of Intramural Research, National Institute of Allergy and Infectious Diseases, National Institutes of Health.

3. Taylor MJ, Hoerauf A, Bockarie M. Lymphatic filariasis and onchocerciasis. Lancet (2010) 376(9747):1175-85. doi:10.1016/ S0140-6736(10)60586-7

4. Ottesen EA. The global programme to eliminate lymphatic filariasis. Trop Med Int Health
(2000) 5(9):591-4. doi:10.1046/j. 1365-3156.2000.00620.x

5. Ottesen EA, Hooper PJ, Bradley M, Biswas $\mathrm{G}$. The global programme to eliminate lymphatic filariasis: health impact after 8 years. PLoS Negl Trop Dis (2008) 2(10):e317. doi:10.1371/ journal.pntd.0000317 
6. Nutman TB, Kumaraswami V. Regulation of the immune response in lymphatic filariasis: perspectives on acute and chronic infection with Wuchereria bancrofti in South India. Parasite Immunol (2001) 23(7):389-99. doi:10.1046/j.13653024.2001.00399.x

7. Yazdanbakhsh M. Common features of $\mathrm{T}$ cell reactivity in persistent helminth infections: lymphatic filariasis and schistosomiasis. Immunol Lett (1999) 65(1-2):109-15. doi:10.1016/ S0165-2478(98)00133-3

8. Ottesen EA. Immediate hypersensitivity responses in the immunopathogenesis of human onchocerciasis. Rev Infect Dis (1985) 7(6):796-801. doi:10.1093/clinids/7.6.796

9. Ottesen EA. Filariasis now. Am J Trop Med Hyg (1989) 41(3 Suppl):9-17.

10. Ottesen EA. Filarial infections. Infect Dis Clin North Am (1993) 7(3):619-33.

11. Ottesen EA. Immune responsiveness and the pathogenesis of human onchocerciasis. J Infect Dis (1995) 171(3):659-71. doi:10. 1093/infdis/171.3.659

12. Maizels RM, Sartono E, Kurniawan A, Partono F, Selkirk ME, Yazdanbakhsh M. T-cell activation and the balance of antibody isotypes in human lymphatic filariasis. Parasitol Today (1995) 11(2):50-6. doi: 10.1016/0169-4758(95)80116-2

13. King CL, Nutman TB. Regulation of the immune response in lymphatic filariasis and onchocerciasis. Immunol Today (1991) 12(3):A54-8. doi:10.1016/S01675699(05)80016-7

14. Zahner H, Sanger I, Chatterjee RK, Seibold G. Altered immune response (humoral and delayedtype hypersensitivity reactions) to sheep red blood cells in the course of experimental filarial infections (Litomosoides carinii, Brugia malayi, Acanthocheilonema viteae) of Mastomys natalensis. Parasitol Res (1989) 75(5):401-11. doi:10. 1007/BF00931137

15. Leiva LE, Lammie PJ. Regulation of parasite antigen-induced $\mathrm{T}$ cell growth factor activity and proliferative responsiveness in Brugia pahangi-infected jirds. J Immunol (1989) 142(4):1304-9.

16. Arasu P, Nutman TB, Steel C, Mulligan MM, Abraham D, Tuan RS, et al. Human T-cell stimulation, molecular characterization and in situ mRNA localization of a Brugia malayi recombinant antigen. Mol Biochem Parasitol (1989) 36(3):223-31. doi:10.1016/ 0166-6851(89)90170-9

17. Canlas MM, Piessens WF. Stagespecific and common antigens of Brugia malayi identified with monoclonal antibodies. J Immunol (1984) 132(6):3138-41.

18. Piessens WF. Lymphatic filariasis in humans: an immunologic maze. Ann Intern Med (1981) 95(6):778-9. doi:10.7326/ 0003-4819-95-6-778

19. Piessens WF, McGreevy PB, Piessens PW, McGreevy M, Koiman I, Saroso JS, et al. Immune responses in human infections with Brugia malayi: specific cellular unresponsiveness to filarial antigens. J Clin Invest (1980) 65(1):172-9. doi:10.1172/JCI109648

20. Cooper PJ, Espinel I, Paredes W, Guderian RH, Nutman TB. Impaired tetanus-specific cellular and humoral responses following tetanus vaccination in human onchocerciasis: a possible role for interleukin-10. J Infect Dis (1998) 178(4):1133-8. doi:10. $1086 / 515661$

21. Elias D, Akuffo H, Britton S. Helminthes could influence the outcome of vaccines against TB in the tropics. Parasite Immunol (2006) 28(10):507-13. doi:10. 1111/j.1365-3024.2006.00854.x

22. Elias D, Britton S, Aseffa A, Engers H, Akuffo H. Poor immunogenicity of BCG in helminth infected population is associated with increased in vitro TGF-beta production. Vaccine (2008) 26(31):3897-902. doi:10.1016/j.vaccine.2008.04.083

23. Hartgers FC, Obeng BB, Kruize YC, Dijkhuis A, McCall M, Sauerwein RW, et al. Responses to malarial antigens are altered in helminth-infected children. J Infect Dis (2009) 199(10):1528-35. doi: $10.1086 / 598687$

24. Metenou S, Dembele B, Konate S, Dolo H, Coulibaly SY, Coulibaly YI, et al. Patent filarial infection modulates malaria-specific type 1 cytokine responses in an IL-10-dependent manner in a filaria/malariacoinfected population. J Immunol (2009) 183(2):916-24. doi:10.4049/jimmunol.0900257

25. Metenou S, Dembele B, Konate S, Dolo H, Coulibaly YI, Diallo AA, et al. Filarial infection suppresses malaria-specific multifunctional Th1 and Th17 responses in malaria and filarial coinfections. $J$
Immunol (2011) 186(8):4725-33. doi:10.4049/jimmunol.1003778

26. Nookala S, Srinivasan S, Kaliraj P, Narayanan RB, Nutman TB. Impairment of tetanus-specific cellular and humoral responses following tetanus vaccination in human lymphatic filariasis. Infect Immun (2004) 72(5):2598-604. doi:10.1128/IAI.72.5.2598-2604. 2004

27. Feuerer M, Hill JA, Mathis D, Benoist C. Foxp3+ regulatory $\mathrm{T}$ cells: differentiation, specification, subphenotypes. Nat Immunol (2009) 10(7):689-95. doi:10.1038/ ni. 1760

28. Gol-Ara M, Jadidi-Niaragh F, Sadria R, Azizi G, Mirshafiey A. The role of different subsets of regulatory $\mathrm{T}$ cells in immunopathogenesis of rheumatoid arthritis. Arthritis (2012) 2012:805875. doi: $10.1155 / 2012 / 805875$

29. Himmel ME, MacDonald KG, Garcia RV, Steiner TS, Levings MK. Helios+ and Helios- cells coexist within the natural FOXP3+ T regulatory cell subset in humans. J Immunol (2013) 190(5):2001-8. doi:10.4049/jimmunol.1201379

30. Horwitz DA, Zheng SG, Gray JD. Natural and TGF-beta-induced Foxp3(+)CD4(+) CD25(+) regulatory $\mathrm{T}$ cells are not mirror images of each other. Trends Immuno (2008) 29(9):429-35. doi:10.1016/ j.it.2008.06.005

31. McClymont SA, Putnam AL, Lee MR, Esensten JH, Liu W, Hulme MA, et al. Plasticity of human regulatory $\mathrm{T}$ cells in healthy subjects and patients with type 1 diabetes. J Immunol (2011) 186(7):3918-26. doi:10.4049/jimmunol.1003099

32. Ottesen EA, Weller PF, Heck L. Specific cellular immune unresponsiveness in human filariasis. Immunology (1977) 33(3):413-21.

33. Lammie PJ, Katz SP. Immunoregulation in experimental filariasis. IV. Induction of non-specific suppression following in vitro exposure of spleen cells from infected jirds to Brugia pahangi antigen. Immunology (1984) 52(2):221-9.

34. Hitch WL, Hightower AW, Eberhard ML, Lammie PJ. Analysis of isotype-specific antifilarial antibody levels in a Haitian pediatric population. Am J Trop Med Hyg (1991) 44(2):161-7.

35. Yazdanbakhsh M, Sartono E, Kruize YC, Kurniawan A, van der Pouw-Kraan T, van der Meide $\mathrm{PH}$ et al. Elevated levels of T cell activation antigen CD27 and increased interleukin-4 production in human lymphatic filariasis. Eur J Immunol (1993) 23(12):3312-7. doi:10.1002/eji.1830231238

36. Nielsen NO, Bloch P, Simonsen PE. Lymphatic filariasis-specific immune responses in relation to lymphoedema grade and infection status. II. Humoral responses. Trans $R$ Soc Trop Med Hyg (2002) 96(4):453-8. doi:10.1016/S00359203(02)90392-5

37. Nutman TB, Kumaraswami V, Ottesen EA. Parasite-specific anergy in human filariasis. Insights after analysis of parasite antigen-driven lymphokine production. J Clin Invest (1987) 79(5):1516-23. doi:10.1172/ JCI1 12982

38. Bosshardt SC, Coleman SU, McVay CS, Jones KL, Klei TR. Impact of microfilaremia on maintenance of a hyporesponsive cellular immune response in Brugia-infected gerbils (Meriones unguiculatus). Infect Immun (1995) 63(3):940-5.

39. Mahanty S, Luke HE, Kumaraswami V, Narayanan PR, Vijayshekaran V, Nutman TB. Stage-specific induction of cytokines regulates the immune response in lymphatic filariasis. Exp Parasitol (1996) 84(2):282-90. doi:10.1006/expr.1996.0114

40. Rao UR, Vickery AC, Kwa BH, Nayar JK. Regulatory cytokines in the lymphatic pathology of athymic mice infected with Brugia malayi. Int J Parasitol (1996) 26(5):561-5. doi:10.1016/00207519(96)00036-7

41. Ravichandran M, Mahanty S, Kumaraswami V, Nutman TB, Jayaraman K. Elevated IL-10 mRNA expression and downregulation of Th1-type cytokines in microfilaraemic individuals with Wuchereria bancrofti infection. Parasite Immunol (1997) 19(2):69-77. doi:10.1046/j.13653024.1997.d01-185.x

42. Maizels RM, Yazdanbakhsh M. Immune regulation by helminth parasites: cellular and molecular mechanisms. Nat Rev Immunol (2003) 3(9):733-44. doi:10.1038/ nril183

43. Babu S, Blauvelt CP, Nutman TB. Filarial parasites induce NK cell activation, type 1 and type 2 cytokine secretion, and subsequent apoptotic cell death. J Immunol (2007) 179(4):2445-56.

44. Babu S, Nutman TB. Proinflammatory cytokines dominate the early immune response to filarial parasites. J Immunol (2003) 171(12):6723-32. 
45. Cooper PJ, Mancero T, Espinel M, Sandoval C, Lovato R, Guderian $\mathrm{RH}$, et al. Early human infection with Onchocerca volvulus is associated with an enhanced parasitespecific cellular immune response. J Infect Dis (2001) 183(11):1662-8. doi:10.1086/320709

46. Devaney E, Osborne J. The third-stage larva (L3) of Brugia: its role in immune modulation and protective immunity. Microbes Infect (2000) 2(11):1363-71. doi: 10.1016/S1286-4579(00)01290-9

47. Taubert A, Zahner H. Cellular immune responses of filaria ( Litomosoides sigmodontis) infected $\mathrm{BALB} / \mathrm{c}$ mice detected on the level of cytokine transcription. Parasite Immunol (2001) 23(8):453-62. doi:10.1046/j.1365-3024.2001. 00405.x

48. Subrahmanyam D. Immune responses to filarial infections. J Commun Dis (1985) 17(1 Suppl):125-7.

49. Loke P, MacDonald AS, Robb A, Maizels RM, Allen JE. Alternatively activated macrophages induced by nematode infection inhibit proliferation via cell-to-cell contact. Eur J Immunol (2000) 30(9):2669-78. doi:10.1002/1521-4141(200009) 30:9<2669::AID-IMMU2669>3. $0 . \mathrm{CO} ; 2-1$

50. Doetze A, Satoguina J, Burchard G, Rau T, Loliger C, Fleischer B, et al. Antigen-specific cellular hyporesponsiveness in a chronic human helminth infection is mediated by $\mathrm{T}(\mathrm{h}) 3 / \mathrm{T}(\mathrm{r}) 1$-type cytokines IL-10 and transforming growth factor-beta but not by a $\mathrm{T}(\mathrm{h}) 1$ to $\mathrm{T}(\mathrm{h}) 2$ shift. Int Immunol (2000) 12(5):623-30. doi:10.1093/ intimm/12.5.623

51. Flynn RJ, Mulcahy G. The roles of IL-10 and TGF-beta in controlling IL-4 and IFN-gamma production during experimental Fasciola hepatica infection. Int $J$ Parasitol (2008) 38(14):1673-80. doi: 10.1016/j.ijpara.2008.05.008

52. Korten S, Hoerauf A, Kaifi JT, Buttner DW. Low levels of transforming growth factor-beta (TGF-beta) and reduced suppression of Th2mediated inflammation in hyperreactive human onchocerciasis. Parasitology (2011) 138(1):35-45. doi:10.1017/S0031182010000922

53. Gershon RK, Kondo K. Cell interactions in the induction of tolerance: the role of thymic lymphocytes. Immunology (1970) 18(5):723-37.

54. Thornton AM, Shevach EM. CD4+CD25+ immunoregulatory
$\mathrm{T}$ cells suppress polyclonal $\mathrm{T}$ cell activation in vitro by inhibiting interleukin 2 production. J Exp Med (1998) 188(2):287-96. doi:10.1084/jem.188.2.287

55. Suri-Payer E, Amar AZ, Thornton AM, Shevach EM. CD4+CD25+ T cells inhibit both the induction and effector function of autoreactive $\mathrm{T}$ cells and represent a unique lineage of immunoregulatory cells. $J$ Immunol (1998) 160(3):1212-8.

56. Sakaguchi S, Sakaguchi N, Asano M, Itoh M, Toda M. Immunologic self-tolerance maintained by activated $\mathrm{T}$ cells expressing IL2 receptor alpha-chains (CD25). Breakdown of a single mechanism of self-tolerance causes various autoimmune diseases. J Immunol (1995) 155(3):1151-64.

57. Ng WF, Duggan PJ, Ponchel F, Matarese G, Lombardi G, Edwards AD, et al. Human CD4(+)CD25(+) cells: a naturally occurring population of regulatory $\mathrm{T}$ cells. Blood (2001) 98(9):2736-44. doi:10.1182/blood.V98.9.2736

58. Levings MK, Sangregorio R, Roncarolo MG. Human cd25(+)cd4(+) t regulatory cells suppress naive and memory $\mathrm{T}$ cell proliferation and can be expanded in vitro without loss of function. $J$ Exp Med (2001) 193(11):1295-302. doi:10.1084/jem.193.11.1295

59. Dieckmann D, Plottner H, Berchtold S, Berger T, Schuler G. Ex vivo isolation and characterization of CD4(+)CD25(+) $\mathrm{T}$ cells with regulatory properties from human blood. J Exp Med (2001) 193(11):1303-10. doi:10. 1084/jem.193.11.1303

60. Abbas AK, Benoist C, Bluestone JA, Campbell DJ, Ghosh S, Hori S, et al. Regulatory $\mathrm{T}$ cells: recommendations to simplify the nomenclature. Nat Immunol (2013) 14(4):307-8. doi:10.1038/ni.2554

61. Lin X, Chen M, Liu Y, Guo Z, He X, Brand D, et al. Advances in distinguishing natural from induced Foxp3(+) regulatory $\mathrm{T}$ cells. Int J Clin Exp Pathol (2013) 6(2):116-23.

62. Benoist C, Mathis D. Treg cells, life history, and diversity. Cold Spring Harb Perspect Biol (2012) 4(9):doi: 10.1101/cshperspect.a007021

63. Peterson RA. Regulatory Tcells: diverse phenotypes integral to immune homeostasis and suppression. Toxicol Pathol (2012) 40(2):186-204. doi:10.1177/0192623311430693
64. Horwitz DA. Regulatory $\mathrm{T}$ cells in systemic lupus erythematosus: past, present and future. Arthritis Res Ther (2008) 10(6):227. doi:10. 1186/ar2511

65. Battaglia M, Roncarolo MG. The role of cytokines (and not only) in inducing and expanding $T$ regulatory type 1 cells. Transplantation (2004) 77(1 Suppl):S16-8. doi:10. 1097/01.TP.0000106468.96542.26

66. Yagi H, Nomura T, Nakamura K, Yamazaki S, Kitawaki T, Hori $\mathrm{S}$, et al. Crucial role of FOXP3 in the development and function of human CD25+CD4+ regulatory $\mathrm{T}$ cells. Int Immunol (2004) 16(11):1643-56. doi:10. 1093/intimm/dxh165

67. Kasprowicz DJ, Smallwood PS, Tyznik AJ, Ziegler SF. Scurfin (FoxP3) controls T-dependent immune responses in vivo through regulation of $\mathrm{CD} 4+\mathrm{T}$ cell effector function. J Immunol (2003) 171(3):1216-23.

68. Babu S, Kumaraswami V, Nutman TB. Transcriptional control of impaired Th1 responses in patent lymphatic filariasis by $\mathrm{T}$ box expressed in $\mathrm{T}$ cells and suppressor of cytokine signaling genes. Infect Immun (2005) 73(6):3394-401. doi:10.1128/IAI 73.6.3394-3401.2005

69. Babu S, Blauvelt CP, Kumaraswami V, Nutman TB. Regulatory networks induced by live parasites impair both Th1 and Th2 pathways in patent lymphatic filariasis: implications for parasite persistence. J Immunol (2006) 176(5):3248-56.

70. Metenou S, Dembele B, Konate S, Dolo H, Coulibaly SY, Coulibaly YI, et al. At homeostasis filarial infections have expanded adaptive $\mathrm{T}$ regulatory but not classical Th2 cells. Immunol (2010) 184(9):5375-82. doi:10.4049/jimmunol.0904067

71. Groux H, O'Garra A, Bigler M, Rouleau M, Antonenko S, de Vries JE, et al. A CD4+ T-cell subset inhibits antigen-specific $\mathrm{T}$ cell responses and prevents colitis. Nature (1997) 389(6652):737-42. doi: $10.1038 / 39614$

72. Roncarolo MG, Gregori S, Battaglia M, Bacchetta R, Fleischhauer K, Levings MK. Interleukin-10-secreting type 1 regulatory $\mathrm{T}$ cells in rodents and humans. Immunol Rev (2006) 212:28-50. doi:10.1111/j.01052896.2006.00420.x

73. Bacchetta R, Gregori S, Roncarolo MG. CD4+ regulatory T cells: mechanisms of induction and effector function. Autoimmun Rev (2005) 4(8):491-6. doi:10.1016/j. autrev.2005.04.005

74. Levings MK, Bacchetta R, Schulz $\mathrm{U}$, Roncarolo MG. The role of IL10 and TGF-beta in the differentiation and effector function of $\mathrm{T}$ regulatory cells. Int Arch Allergy Immunol (2002) 129(4):263-76. doi:10.1159/000067596

75. Roncarolo MG, Bacchetta R, Bordignon C, Narula S, Levings MK. Type $1 \mathrm{~T}$ regulatory cells. Immunol Rev (2001) 182:68-79. doi:10. 1034/j.1600-065X.2001.1820105.x

76. Chen Y, Kuchroo VK, Inobe J, Hafler DA, Weiner HL. Regulatory $\mathrm{T}$ cell clones induced by oral tolerance: suppression of autoimmune encephalomyelitis. Science (1994) 265(5176):1237-40. doi:10 $1126 /$ science.7520605

77. Weiner HL. Induction and mechanism of action of transforming growth factor-beta-secreting Th3 regulatory cells. Immunol Rev (2001) 182:207-14. doi:10.1034/j. 1600-065X.2001.1820117.x

78. Weiner HL. Oral tolerance: immune mechanisms and the generation of Th3-type TGF-betasecreting regulatory cells. Microbes Infect (2001) 3(11):947-54. doi: 10.1016/S1286-4579(01)01456-3

79. Soboslay PT, Geiger SM, Weiss N, Banla M, Luder CG, Dreweck $\mathrm{CM}$, et al. The diverse expression of immunity in humans at distinct states of Onchocerca volvulus infection. Immunology (1997) 90(4):592-9. doi:10.1046/j.13652567.1997.00210.x

80. King CL, Low CC, Nutman TB. IgE production in human helminth infection. Reciprocal interrelationship between IL-4 and IFN-gamma. J Immunol (1993) 150(5):1873-80.

81. King CL, Nutman TB. IgE and IgG subclass regulation by IL-4 and IFN-gamma in human helminth infections. Assessment by B cell precursor frequencies. I Immunol (1993) 151(1):458-65.

82. Kurniawan A, Yazdanbakhsh M, van Ree R, Aalberse R, Selkirk ME, Partono F, et al. Differential expression of IgE and IgG4 specific antibody responses in asymptomatic and chronic human filariasis. $J$ Immunol (1993) 150(9):3941-50.

83. Kwan-Lim GE, Forsyth KP, Maizels RM. Filarial-specific IgG4 response correlates with active Wuchereria bancrofti infection. J Immunol (1990) 145(12):4298-305. 
84. Dimock KA, Addiss DG, Eberhard ML, Lammie PJ. Differential proliferative and interleukin10 responses to fractionated filarial antigens: preferential recognition by patients with chronic lymphatic dysfunction. J Infect Dis (1994) 170(2): 403-12. doi:10.1093/infdis/170.2. 403

85. Mahanty S, Mollis SN, Ravichandran M, Abrams JS, Kumaraswami V, Jayaraman K, et al. High levels of spontaneous and parasite antigen-driven interleukin-10 production are associated with antigen-specific hyporesponsiveness in human lymphatic filariasis. J Infect Dis (1996) 173(3):769-73. doi:10.1093/infdis/173.3.769

86. Mahanty S, Nutman TB. Immunoregulation in human lymphatic filariasis: the role of interleukin 10. Parasite Immunol (1995) 17(8):385-92. doi:10.1111/ j.1365-3024.1995.tb00906.x

87. Steel C, Nutman TB. CTLA4 in filarial infections: implications for a role in diminished $\mathrm{T}$ cell reactivity. J Immunol (2003) 170(4):1930-8.

88. Mahanty S, Ravichandran M, Raman U, Jayaraman K, Kumaraswami V, Nutman TB. Regulation of parasite antigendriven immune responses by interleukin-10 (IL-10) and IL-12 in lymphatic filariasis. Infect Immun (1997) 65(5):1742-7.

89. Simons JE, Gray CA, Lawrence RA. Absence of regulatory IL-10 enhances innate protection against filarial parasites by a neutrophilindependent mechanism. Parasite Immunol (2010) 32(7):473-8. doi:10.1111/j.1365-3024.2010. 01210.x

90. Taylor MD, Harris A, Nair MG, Maizels RM, Allen JE. F4/80+ alternatively activated macrophages control CD4+ T cell hyporesponsiveness at sites peripheral to filarial infection. J Immunol (2006) 176(11):6918-27.

91. Hussain R, Ottesen EA. IgE responses in human filariasis. IV. Parallel antigen recognition by $\operatorname{IgE}$ and IgG4 subclass antibodies. $J$ Immunol (1986) 136(5):1859-63.

92. Simonsen PE, Lemnge MM, Msangeni HA, Jakobsen PH, Bygbjerg IC. Bancroftian filariasis: the patterns of filarial-specific immunoglobulin G1 (IgG1), IgG4, and circulating antigens in an endemic community of northeastern Tanzania. Am J Trop Med Hyg (1996) 55(1):69-75.
93. Wamae CN, Lammie PJ, Muttunga JN. Bancroftian filariasis: profile of serum antifilarial antibody and circulating parasite antigen. East Afr Med J (1995) 72(8): 492-4.

94. Yazdanbakhsh M, Paxton WA, Kruize YC, Sartono E, Kurniawan A, van het Wout $A$, et al. $\mathrm{T}$ cell responsiveness correlates differentially with antibody isotype levels in clinical and asymptomatic filariasis. J Infect Dis (1993) 167(4):925-31. doi:10. 1093/infdis/167.4.925

95. Joseph SK, Verma SK, Sahoo MK, Dixit S, Verma AK, Kushwaha V, et al. Sensitization with anti-inflammatory BmAFI of $\mathrm{Bru}$ gia malayi allows L3 development in the hostile peritoneal cavity of Mastomys coucha. Acta Trop (2011) 120(3):191-205. doi: 10.1016/j.actatropica.2011.08.005

96. Adjobimey T, Hoerauf A. Induction of immunoglobulin G4 in human filariasis: an indicator of immunoregulation. Ann Trop Med Parasitol (2010) 104(6):455-64. doi:10.1179/ 136485910X12786389891407

97. Noordin R, Itoh M, Kimura E, Abdul Rahman R, Ravindran B, Mahmud R, et al. Multicentre evaluations of two new rapid IgG4 tests (WB rapid and panLF rapid) for detection of lymphatic filariasis. Filaria J (2007) 6:9. doi:10.1186/ 1475-2883-6-9

98. Briere F, Servet-Delprat C, Bridon JM, Saint-Remy JM, Banchereau J. Human interleukin 10 induces naive surface immunoglobulin $\mathrm{D}+$ (sIgD+) B cells to secrete IgG1 and IgG3. J Exp Med (1994) 179(2):757-62. doi:10.1084/jem. 179.2.757

99. Malisan F, Fluckiger AC, Ho S, Guret C, Banchereau J, MartinezValdez H. B-chronic lymphocytic leukemias can undergo isotype switching in vivo and can be induced to differentiate and switch in vitro. Blood (1996) 87(2):717-24.

100. Satoguina JS, Adjobimey T, Arndts $\mathrm{K}$, Hoch J, Oldenburg J, Layland LE, et al. Trl and naturally occurring regulatory $\mathrm{T}$ cells induce IgG4 in B cells through GITR/GITR-L interaction, IL-10 and TGF-beta. Eur J Immunol (2008) 38(11):3101-13. doi:10. 1002/eji.200838193

101. Gillan V, Lawrence RA, Devaney E. B cells play a regulatory role in mice infected with the L3 of Brugia pahangi. Int Immunol
(2005) 17(4):373-82. doi:10.1093/ intimm/dxh217

102. MacDonald KP, Pettit AR, Quinn C, Thomas GJ, Thomas R. Resistance of rheumatoid synovial dendritic cells to the immunosuppressive effects of IL-10. I Immunol (1999) 163(10):5599-607.

103. Osborne J, Devaney E. Interleukin10 and antigen-presenting cells actively suppress Thl cells in $\mathrm{BALB} / \mathrm{c}$ mice infected with the filarial parasite Brugia pahangi. Infect Immun (1999) 67(4):1599-605.

104. Allen JE, Lawrence RA, Maizels RM. APC from mice harbouring the filarial nematode, Brugia malayi, prevent cellular proliferation but not cytokine production. Int Immunol (1996) 8(1):143-51. doi:10.1093/intimm/8.1.143

105. Takahashi T, Kuniyasu Y, Toda M, Sakaguchi N, Itoh M, Iwata M, et al. Immunologic self-tolerance maintained by $\mathrm{CD} 25+\mathrm{CD} 4+$ naturally anergic and suppressive $\mathrm{T}$ cells: induction of autoimmune disease by breaking their anergic/suppressive state. Int Immuno (1998) 10(12):1969-80. doi:10 1093/intimm/10.12.1969

106. Taams LS, Smith J, Rustin MH, Salmon M, Poulter LW, Akbar AN. Human anergic/suppressive CD4(+)CD25(+) T cells: a highly differentiated and apoptosis-prone population. Eur J Immunol (2001) 31(4):1122-31. doi:10.1002/15214141(200104)31:4<1122::AIDIMMU1122>3.0.CO;2-P

107. McSorley HJ, Harcus YM, Murray J, Taylor MD, Maizels RM. Expansion of Foxp3+ regulatory $\mathrm{T}$ cells in mice infected with the filarial parasite Brugia malayi. J Immunol (2008) 181(9):6456-66.

108. Taylor MD, Harris A, Babayan SA, Bain O, Culshaw A, Allen JE, et al. CTLA-4 and CD4+ CD25+ regulatory $\mathrm{T}$ cells inhibit protective immunity to filarial parasites in vivo. J Immunol (2007) 179(7):4626-34

109. Taylor MD, LeGoff L, Harris A, Malone E, Allen JE, Maizels RM. Removal of regulatory $\mathrm{T}$ cell activity reverses hyporesponsiveness and leads to filarial parasite clearance in vivo. $J$ Immunol (2005) 174(8):4924-33.

110. Taylor MD, van der Werf $\mathrm{N}$, Harris A, Graham AL, Bain $\mathrm{O}$, Allen JE, et al. Early recruitment of natural CD4+ Foxp3+ Treg cells by infective larvae determines the outcome of filarial infection. Eur J Immunol (2009)
39(1):192-206. doi:10.1002/eji. 200838727

111. Wammes LJ, Hamid F, Wiria AE, Wibowo H, Sartono E, Maizels $\mathrm{RM}$, et al. Regulatory $\mathrm{T}$ cells in human lymphatic filariasis: stronger functional activity in microfilaremics. PLoS Negl Trop Dis (2012) 6(5):e1655. doi:10. 1371/journal.pntd.0001655

112. Ma D, Hong X, Raghavan N, Scott AL, McCarthy JS, Nutman TB, et al. A Cyclosporin A-sensitive small molecular weight cyclophilin of filarial parasites. Mol Biochem Parasitol (1996) 79(2):235-41. doi:10. 1016/0166-6851(96)02654-0

113. Verhagen J, Wraith DC. Comment on "Expression of Helios, an Ikaros transcription factor family member, differentiates thymic-derived from peripherally induced Foxp3+ $\mathrm{T}$ regulatory cells." J Immunol (2010) 185(12):7129. doi:10.4049/ jimmunol.1090105

114. Thornton AM, Korty PE, Tran DQ, Wohlfert EA, Murray PE, Belkaid Y, et al. Expression of Helios, an Ikaros transcription factor family member, differentiates thymic-derived from peripherally induced Foxp3+ T regulatory cells. J Immunol (2010) 184(7):3433-41. doi:10.4049/jimmunol.0904028

115. Grainger JR, Smith KA, Hewitson JP, McSorley HJ, Harcus Y, Filbey KJ, et al. Helminth secretions induce de novo $\mathrm{T}$ cell Foxp3 expression and regulatory function through the TGF-beta pathway. $J$ Exp Med (2010) 207(11):2331-41. doi:10.1084/jem.20101074

116. Bennuru S, Meng Z, Ribeiro JM, Semnani RT, Ghedin E, Chan $\mathrm{K}$, et al. Stage-specific proteomic expression patterns of the human filarial parasite Brugia malayi and its endosymbiont Wolbachia. Proc Natl Acad Sci U S A (2011) 108(23):9649-54. doi:10. 1073/pnas. 1011481108

117. Bennuru S, Semnani R, Meng $\mathrm{Z}$, Ribeiro JM, Veenstra TD, Nutman TB. Brugia malayi excreted/secreted proteins at the host/parasite interface: stage- and gender-specific proteomic profiling. PLoS Negl Trop Dis (2009) 3(4):e410. doi:10.1371/journal.pntd.0000410

118. Gomez-Escobar N, Gregory WF, Maizels RM. Identification of tgh2, a filarial nematode homolog of Caenorhabditis elegans daf-7 and human transforming growth factor beta, expressed in microfilarial and adult stages of $\mathrm{Bru}$ gia malayi. Infect Immun (2000) 
68(11):6402-10. doi:10.1128/IAI. 68.11.6402-6410.2000

119. Korten S, Buttner DW, Schmetz C, Hoerauf A, Mand S, Brattig N. The nematode parasite Onchocerca volvulus generates the transforming growth factor-beta (TGF-beta). Parasitol Res (2009) 105(3):731-41. doi:10. 1007/s00436-009-1450-9

120. Korten S, Badusche M, Buttner DW, Hoerauf A, Brattig N, Fleischer B. Natural death of adult Onchocerca volvulus and filaricidal effects of doxycycline induce local FOXP3+/CD4+ regulatory $\mathrm{T}$ cells and granzyme expression. Microbes Infect (2008) 10(3):313-24. doi:10.1016/j.micinf.2007.12.004

121. Satoguina J, Mempel M, Larbi J, Badusche M, Loliger C, Adjei $\mathrm{O}$, et al. Antigen-specific $\mathrm{T}$ regulatory-1 cells are associated with immunosuppression in a chronic helminth infection (onchocerciasis). Microbes Infect (2002) 4(13):1291-300. doi:10 1016/S1286-4579(02)00014-X

122. Mitre E, Chien D, Nutman TB. $\mathrm{CD} 4(+)$ (and not CD25+) T cells are the predominant interleukin10-producing cells in the circulation of filaria-infected patients. $J$ Infect Dis (2008) 197(1):94-101. doi:10.1086/524301

123. Bianchini R, Bistoni O, Alunno A, Petrillo MG, Ronchetti S, Sportoletti P, et al. $\mathrm{CD} 4(+)$ CD25(low) GITR(+) cells: a novel human $\mathrm{CD} 4(+)$ T-cell population with regulatory activity. Eur J Immunol (2011) 41(8):2269-78. doi:10.1002/eji.201040943

124. Buisson S, Triebel F. LAG-3 (CD223) reduces macrophage and dendritic cell differentiation from monocyte precursors. Immunology (2005) 114(3):369-74. doi:10. 1111/j.1365-2567.2004.02087.x

125. Macon-Lemaitre L, Triebel F. The negative regulatory function of the lymphocyte-activation gene-3 co-receptor (CD223) on human T cells. Immunology (2005) 115(2):170-8. doi:10.1111/j.13652567.2005.02145.x

126. Liang S, Spear RC. Model-based insights into multi-host transmission and control of schistosomiasis. PLoS Med (2008) 5(1):e23. doi: 10.1371/journal.pmed.0050023

127. Esquerre M, Tauzin B, Guiraud M, Muller S, Saoudi A, Valitutti S. Human regulatory T cells inhibit polarization of $\mathrm{T}$ helper cells toward antigen-presenting cells via a TGF-beta-dependent mechanism. Proc Natl Acad Sci U $S$ A (2008) 105(7):2550-5. doi:10. 1073/pnas.0708350105

128. Babu S, Blauvelt CP, Kumaraswami V, Nutman TB. Diminished expression and function of TLR in lymphatic filariasis: a novel mechanism of immune dysregulation. $J$ Immunol (2005) 175(2):1170-6.

129. Babu S, Kumaraswami V, Nutman TB. Alternatively activated and immunoregulatory monocytes in human filarial infections. $J$ Infect Dis (2009) 199(12):1827-37. doi: $10.1086 / 599090$

130. Mukhopadhyay S, Sahoo PK, George A, Bal V, Rath S, Ravindran B. Delayed clearance of filarial infection and enhanced Th1 immunity due to modulation of macrophage APC functions in xid mice. J Immunol (1999) 163(2):875-83.

131. Schonemeyer A, Lucius R, Sonnenburg B, Brattig N, Sabat R, Schilling $\mathrm{K}$, et al. Modulation of human $\mathrm{T}$ cell responses and macrophage functions by onchocystatin, a secreted protein of the filarial nematode Onchocerca volvulus. J Immunol (2001) 167(6):3207-15.

132. Semnani RT, Mahapatra L, Dembele B, Konate S, Metenou S, Dolo $\mathrm{H}$, et al. Expanded numbers of circulating myeloid dendritic cells in patent human filarial infection reflect lower CCR1 expression. J Immunol (2010) 185(10):6364-72. doi:10.4049/ jimmunol.1001605
133. Semnani RT, Venugopal PG, Leifer CA, Mostbock S, Sabzevari $\mathrm{H}$, Nutman TB. Inhibition of TLR3 and TLR4 function and expression in human dendritic cells by helminth parasites. Blood (2008) 112(4):1290-8. doi:10. 1182/blood-2008-04-149856

134. Specht S, Volkmann L, Wynn T, Hoerauf A. Interleukin-10 (IL-10) counterregulates IL-4-dependent effector mechanisms in Murine Filariasis. Infect Immun (2004) 72(11):6287-93. doi:10.1128/IAI 72.11.6287-6293.2004

135. Fernandez Ruiz D, Dubben B, Saeftel M, Endl E, Deininger S, Hoerauf A, et al. Filarial infection induces protection against $\mathrm{P}$. berghei liver stages in mice. Microbes Infect (2009) 11(2):172-80. doi:10.1016/ j.micinf.2008.11.003

136. Graham AL, Lamb TJ, Read AF Allen JE. Malaria-filaria coinfection in mice makes malarial disease more severe unless filarial infection achieves patency. J Infect Dis (2005) 191(3):410-21. doi:10. 1086/426871

137. Metenou S, Babu S, Nutman TB. Impact of filarial infections on coincident intracellular pathogens: Mycobacterium tuberculosis and Plasmodium falciparum. Curr Opin HIV AIDS (2012) 7(3):231-8. doi: 10.1097/COH.0b013e3283522c3d

138. Specht S, Ruiz DF, Dubben B, Deininger S, Hoerauf A. Filariainduced IL-10 suppresses murine cerebral malaria. Microbes Infect (2010) 12(8-9):635-42. doi:10 1016/j.micinf.2010.04.006

139. Babu S, Bhat SQ, Kumar NP, Jayantasri S, Rukmani S, Kumaran $P$, et al. Human type 1 and 17 responses in latent tuberculosis are modulated by coincident filarial infection through cytotoxic $\mathrm{T}$ lymphocyte antigen-4 and programmed death-1.J Infect Dis (2009) 200(2):288-98. doi:10. $1086 / 599797$

140. Hubner MP, Shi Y, Torrero MN, Mueller E, Larson D, Soloviova K, et al. Helminth protection against autoimmune diabetes in nonobese diabetic mice is independent of a type 2 immune shift and requires TGF-beta. $J$ Immunol (2012) 188(2):559-68. doi:10.4049/jimmunol.1100335

141. Hubner MP, Stocker JT, Mitre E. Inhibition of type 1 diabetes in filaria-infected non-obese diabetic mice is associated with a $\mathrm{T}$ helper type 2 shift and induction of FoxP3+ regulatory $\mathrm{T}$ cells. Immunology (2009) 127(4):512-22. doi:10.1111/j. 1365-2567.2008.02958.x

Conflict of Interest Statement: Because Simon Metenou and Thomas B. Nutman are government employees and this is a government work, the work is in the public domain in the United States. Notwithstanding any other agreements, the NIH reserves the right to provide the work to PubMedCentral for display and use by the public, and PubMedCentral may tag or modify the work consistent with its customary practices. You can establish rights outside of the U.S. subject to a government use license.

Received: 31 May 2013; accepted: 13 September 2013; published online: 30 September 2013.

Citation: Metenou $S$ and Nutman $T B$ (2013) Regulatory $T$ cell subset in filarial infection and their function. Front. Immunol. 4:305. doi: 10.3389/fimmu.2013.00305

This article was submitted to Immunological Tolerance, a section of the journal Frontiers in Immunology.

Copyright $\odot 2013$ Metenou and Nutman. This is an open-access article distributed under the terms of the Creative Commons Attribution License (CC BY). The use, distribution or reproduction in other forums is permitted, provided the original author(s) or licensor are credited and that the original publication in this journal is cited, in accordance with accepted academic practice. No use, distribution or reproduction is permitted which does not comply with these terms. 